УДК 550.46: 556.56

\title{
МИКРОБИОЛОГИЧЕСКИЕ УСЛОВИЯ РАСПРЕДЕЛЕНИЯ ХИМИЧЕСКИХ ЭЛЕМЕНТОВ ПО ГЛУБИНЕ ТОРФЯНОЙ ЗАЛЕЖИ В ЭКОСИСТЕМАХ ВОСТОЧНОЙ ЧАСТИ ВАСЮГАНСКОГО БОЛОТА (ЗАПАДНАЯ СИБИРЬ)
}

\author{
Савичев Олег Геннадьевич, \\ OSavichev@mail.ru
}

Наливайко Нина Григорьевна,

biologistngn@yandex.ru

Рудмин Максим Андреевич,

RudminMA@tpu.ru

\author{
Мазуров Алексей Карпович, \\ AKM@tpu.ru \\ 1 Национальный исследовательский Томский политехнический университет, \\ Россия, 634050, г. Томск, пр. Ленина, 30.
}

\begin{abstract}
Актуальность определяется необходимостью учета взаимосвязей между распределением химических элементов по глубине торфяной залежи, процессами формирования, эволюции и деградации болот при решении целого ряда фундаментальных и прикладных задач изучения, использования и охраны болот.

Цель: оценка микробиологических условий распределения химических элементов по глубине торфяной залежи и выявление связей между геохимическими и микробиологическими показателями торфов в восточной части Васюганского болота.

Методы: методы химического и микробиологического анализа (включая масс-спектрометрический с индуктивно связанной плазмой), статистические методы.

Результаты и выводы. Выполнен химический, минералогический и микробиологических анализ проб торфов и минерального грунта, отобранных 09.11.2018 г. в восточной части Васюганского болота (граница водораздела рек ключ и Гавриловка - элементов речной сети: (Ключ-Бакчар; Гавриловка-Икса) - Чая-Обь; внутриболотные экосистемы: олиготрофный грядово-мочажинный комплекс, гряда; олиготрофное сосново-кустарничково-сфагнового болота - рям; мезотрофное сосново-кустарничковое болото на границе ряма с заболоченным лесом - мезотрофная окраина. Показано, что, во-первых, болотная микрофлора является очень важным фактором распределения химических элементов по глубине торфяной залежи в различных внутриболотных экосистемах восточной части Васюганского болота. Вероятность накопления в торфах малорастворимых соединений кальция, железа и редкоземельных элементов возрастает по мере усиления анаэробных условий развития болотной микрофлоры, определяющих увеличение рН болотной среды до 7,8 и выше, что приводит к смещению карбонатного равновесия и выпадению малорастворимых соединений кальция. Во-вторых, возможность выведения из раствора гидроксидов железа является характерной особенностью геохимии торфяных болот на фоне незначительной, но постоянно наблюдаемой активности железобактерий, образующих гидроксиды железа. В-третьих, вследствие сорбционных процессов на гидроокислах железа (и малорастворимых соединениях кальция в нижних слоях торфяной залежи) происходит осаждение гидроокислов, фосфатов и карбонатов (возможно - сульфатов и сульфидов) ряда микроэлементов, включая редкоземельные элементы.
\end{abstract}

\section{Ключевые слова:}

Микробиологические условия, распределение химических элементов, торфяная залежь, Васюганское болото, Западная Сибирь.

\section{Введение}

Распределение химических элементов по глубине торфяной залежи является важной характеристикой процессов формирования, эволюции и деградации болот (далее - болотных процессов). Это определяет актуальность соответствующих исследований, несмотря на значительное количество работ в этом направлении, в том числе и по Западной Сибири - одному из самых заболоченных в мире регионов [1-5]. В частности, было установлено, что, во-первых, изученные химические элементы можно условно разделить на три основные группы: 1.1) с относительно устойчивым увеличением от поверхности к минеральным грунтам и/или ярко выраженным максимумом в минеральных грунтах - Li, Al, Be, Mg, Ca, Sr, Fe, V, Cr, Mn, Ni, J, Ba,
Cs, Ce, La, Sm, Eu, Dy, Tb, Yb, Lu, Ho, Gd, Th, в том числе с небольшим повышением концентраций в верхней части разреза $\mathrm{Cu}, \mathrm{Ga}, \mathrm{Ge}, \mathrm{Rb}, \mathrm{Zr}, \mathrm{Hf}$; 1.2) с хорошо выраженными максимумами в верхней и нижней частях разреза - $\mathrm{Na}, \mathrm{K}, \mathrm{Ti}, \mathrm{Pb}, \mathrm{Hg}$, $\mathrm{Rb}, \mathrm{Cd}, \mathrm{Sb}, \mathrm{Sn}, \mathrm{W}, \mathrm{Bi}, \mathrm{Si} ; 1.3)$ с иными типами распределения либо с отсутствием общих закономерностей - S, P, U, Au, Ag, Pt, Zn, As, Re, Os, B, Br, Ta [6]. Во-вторых, на основе результатов математического моделирования распространения по глубине химических элементов в водных и кислотных вытяжках торфов, органо-минеральных отложений и минерального грунта показано, что в торфяной залежи функционирует два комплексных геохимических барьера, связанных с изменениями фильтрационных свойств грунтов и способствую- 
щих формированию и/или накоплению в торфяной залежи соединений Fе и ряда других химических элементов: 2.1) первый барьер - окислительный, восстановительный, сульфидный и сорбционный гидроксидный - расположен примерно на глубинах от 0,40 до $1,25 \mathrm{~m} ; 2.2)$ второй барьер - щелочной карбонатный и гидролитический, сорбционный гидроксидный, глинистый и карбонатный - в нижнем слое торфяной залежи [7].

В случае нижнего гидрогеохимического барьера требуется дополнительная информация о биогеохимических процессах, в результате которых существенно меняется $\mathrm{pH}$ водной среды (от $3,5-5,5$ до 7,5-8,2). Согласно [8-12], один из механизмов таких изменений может быть связан с анаэробным дыханием микроорганизмов в условиях дефицита растворенного кислорода. С целью подтверждения этой гипотезы применительно к торфяной залежи в 2018-2019 гг. в Томском политехническом университете (ТПУ) было выполнено рассматриваемое исследование болотной микрофлоры.

\section{Объект и методика исследования}

Объектом исследования является восточная часть Васюганского болота (Западная Сибирь) в районе с. Полынянка (Бакчарский административный район Томской области, Российская Федерация), в пределах которой расположены следующие внутриболотные экосистемы: 1) олиготрофный грядово-мочажинный комплекс (опробовалась торфяная залежь на гряде в пункте с координатами 56,937 северной широты (с.ш.); $82,698^{\circ}$ восточной долготы (в.д.)); 2) олиготрофное сосново-кустарничково-сфагнового болота (далее используется региональное название - «рям»; 56,927 $82,700^{\circ}$ в.д.); 3) мезотрофное сосново-кустарничковое болото на границе ряма с заболоченным лесом (далее используется термин «мезотрофная окраина»; $56.921^{\circ}$ с.ш.; $82.704^{\circ}$ в.д.). Более подробная характеристика исследуемой части Васюганского болота приведена в $[6,13,14]$.

Основной акцент в исследовании был сделан на отбор и анализ вытяжек из торфов и минерального грунта, отобранных на трех указанных выше участках по интервалам 0,25 м. Отбор проб проводился 09.11.2018 г. согласно [15] при отрицательной температуре атмосферного воздуха. Пробы торфа и минерального грунта были помещены в полиэтиленовые емкости и в течение рабочего дня доставлены в аккредитованную гидрогеохимическую лабораторию ТПУ, где были подготовлены для химического и микробиологического анализа. В кислотных вытяжках из предварительно высушенных образцов (методика пробоподготовки для химического анализа приведена в [6] с использованием масс-спектрометрического метода с индуктивно связанной плазмой (масс-спектрометр NexION 300D) выполнено определение концентраций 73 химических элементов, включая $\mathrm{Ca}, \mathrm{Mg}, \mathrm{Na}, \mathrm{K}$, $\mathrm{P}, \mathrm{Si}, \mathrm{Al}, \mathrm{Fe}, \mathrm{Mn}$ и ряд других. В водных вытяжках проведено определение $\mathrm{pH}$ и удельной электропроводности $\chi$. Изучение минерального состава включений в торфа было выполнено в ТПУ методом электронной микроскопии. Методика определения минерального состава также приведена в [6].

Исследование микрофлоры проводилось в торфяных вытяжках из проб торфов (и минерального грунта) с естественной влажностью. Пробоподготовка включала следующие операции. Предварительно из проб торфа (с соблюдением стерильности) удаляли стебли, корни растений, другие включения. Затем торф в закрытом пакете перемешивали, после чего, не вынимая из пакета, его раскладывали ровным слоем на столе. Из разных мест распределенного слоя торфа стерильным шпателем отбирали небольшие порции и в стерильной, предварительно тарированной фарфоровой чашке, взвешивали 1 г среднего образца. Полученную навеску помещали в стерильный флакон и заливали 100 мл стерильной водопроводной воды. Флакон с торфяной суспензией встряхивали в течение 15 мин, после чего давали ей отстояться в течение 5 мин и сразу использовали ее для приготовления разведений и посева. При этом учитывали, что в полученной исходной суспензии исследуемый материал (торф) разведен в 100 раз.

При изучении микрофлоры использовались классические методики, принятые в микробиологии $[16,17]$. Сапрофиты, как основные деструкторы органического вещества, выявляли посевом аликвоты на мясопептонный агар и культивировали при температуре 22 и $37^{\circ} \mathrm{C}$. Гетеротрофные микроорганизмы, окисляющие восстановленные формы железа (далее - Fе-окисляющие), определяли на твердой среде Калиненко при температуре $22-25{ }^{\circ} \mathrm{C}$ в течение 10-15 сут. Аммонифицирующие микроорганизмы, принимающие участие в расщеплении белковых соединений до аммиака, определяли при температуре $22-25{ }^{\circ} \mathrm{C}$ в течение 10-15 дней с использованием мясопептонного бульона (и индикаторов, показывающих наличие аммиака). Денитрифицирующие бактерии выявляли на среде Гильтая методом предельных разведений, инкубируя их при $22-25{ }^{\circ} \mathrm{C}$ в течение двух недель. Признаком наличия в среде бактерий служило изменение $\mathrm{pH}$, цвета культуральной жидкости, появление в среде азота или аммиака, что фиксировалось по появлению пены. Количество нитрифицирующих бактерий, завершающих цикл превращения в почве азотсодержащих соединений, определяли путем посева торфяной суспензии на жидкую минеральную среду Виноградского методом предельных разведений. Посевы инкубировали при $25-28{ }^{\circ} \mathrm{C}$ в течение $14-15$ сут.

Сульфатредуцирующие бактерии культивировались на среде Таусона-Штурм с лактатом кальция в качестве источника органического вещества. Посев осуществляли способом предельных разведений. Об интенсивности процесса редукции сульфатов судили по появлению в среде черного осадка сульфида железа. Тионовые бактерии представля- 
ют единую в морфологическом и биохимическом отношении группу. Все они способны использовать энергию окисления восстановленных соединений серы в серную кислоту для ассимиляции углерода, построения клеточного тела и всех остальных функций. Эти бактерии выращивали на твердых и жидких средах, в которые добавляли тиосульфаты. Нефтеокисляющие бактерии, как показатели наличия углеводородов в среде обитания, учитывали на агаризованной среде Мюнца с нефтью в качестве единственного источника углерода и энергии $[16,17]$. Более подробное описание методов микробиологических исследований приведено в [18].

Для получения сопоставимых результатов производился пересчет количества обнаруженных микроорганизмов на 1 г абсолютно сухой почвы. С этой целью навеску грунта (10-20 г) помещали в заранее взвешенный металлический бюкс и высушивали в сушильном шкафу при $105{ }^{\circ} \mathrm{C}$. Первое контрольное взвешивание высушенной почвы делали через 3 часа, затем высушивали торф до постоянного веса (контрольное взвешивание каждые 2 часа). Расчет производится по следующей формуле:

$$
N=\frac{N_{c} \cdot 100}{100-w} N_{c}=n A,
$$

где $N$ - количество клеток бактерий в 1 г абсолютно сухой почвы; $N_{c}-$ количество клеток бактерий в 1 г влажной почвы; $A$ - степень разведения; $n$ среднее арифметическое значение колоний, выросших во всех чашках; $w$ - влажность грунта, \% .

Статистический анализ полученных данных включал расчет среднего, дисперсии, коэффициентов корреляции, проверку на экстремумы и поиск регрессионных зависимостей между геохимическими и микробиологическими показателями с учетом требований [19]. Корреляционные связи принимались статистически значимыми (с уровнем значимости $5 \%$ ) при соблюдении условия

$|r| \geq \frac{2\left(1-r^{2}\right)}{\sqrt{N-1}}$, а регрессионные - при условии

$R^{2}>0,36$ и $\left|k_{r}\right| \geq \delta_{k}$, где $r$ - коэффициент корреляции; $k_{r}$ - коэффициент регрессии; $\delta_{k}-$ погрешность определения коэффициента регрессии; $N$ - объем выборки; $R^{2}$ - квадрат корреляционного отношения [20]. Bсе расчеты выполнены в пакете MS Excel.

\section{Результаты исследования и их обсуждение}

По данным, полученным в ноябре 2018 г., величина $\mathrm{pH}$ водных вытяжек из торфов последовательно увеличивается от $3,5-4,0$ у поверхности до 4,8-5,7 в нижних слоях торфяной залежи, а затем достаточно резко возрастает у верхней границы минерального грунта до 6,1-7,8 (в 2017 г. были отмечены значения до 8,2 $[6,7])$. Удельная электропроводность водных вытяжек также резко повышается на нижней границе торфяной залежи, но, в отличие от $\mathrm{pH}$, принимает минимальные значения не в верхней, а в средней части залежи (рис. 1, 2; табл. 1).

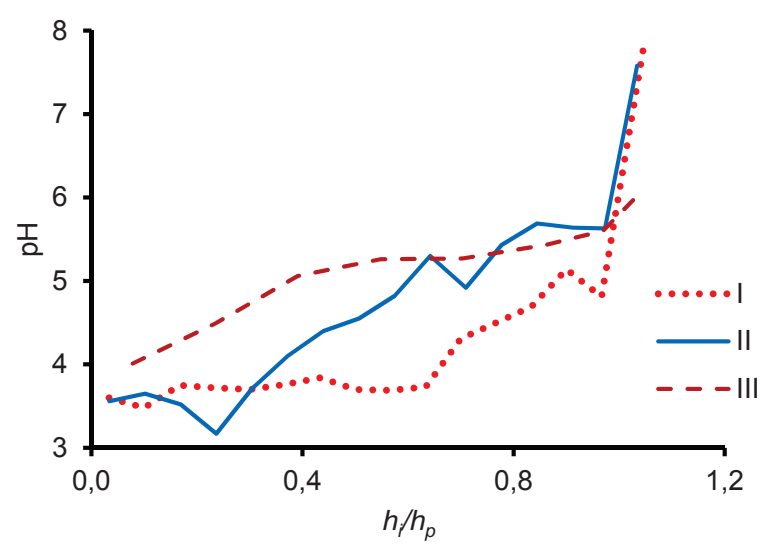

Pис.1. Изменение величины рН водной вытяжки по глубине торфяной залежи в гряде ГМК (I), ряме (II) и на мезотрофной окраине (III); $h_{i} / h_{p}$ - относительная глубина; $h_{i}$ - среднял глубина интервала опробования, м; $h_{p}-$ мощность торфяной залежи,

Fig. 1. Change of $p H$ in water extracts on peat deposit depth in the ridge of $H R C$ (I), ryam (II) and mesotrophic border (III); $h_{i} / h_{p}$ is the relative depth; $h_{i}$ is the average depth of approbation interval, $m$; $h_{p}$ is the capacity of a peat deposit, $m$

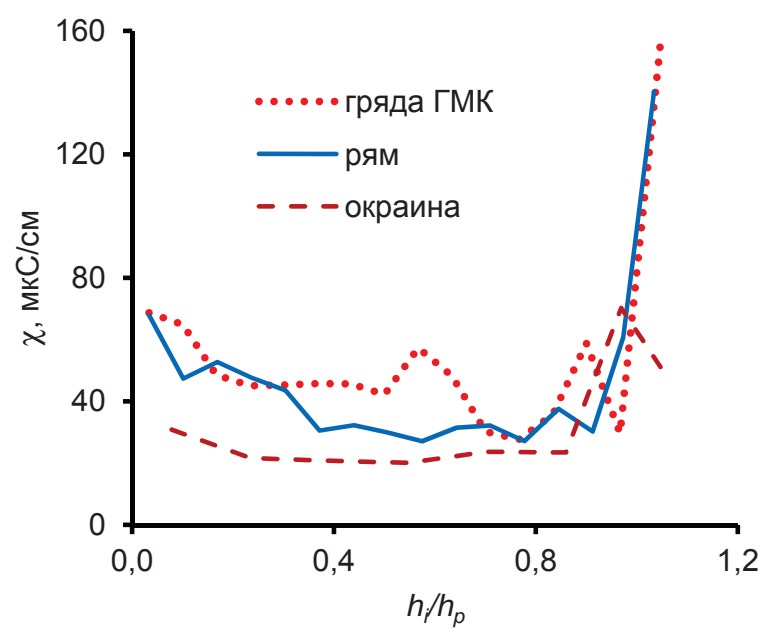

Pис. 2. Изменение величины удельной электропроводности ұводной вытяжки по глубине торфяной залежи в гряде ГМК (I), ряме (II) и на мезотрофной окраине (III); $h_{\mathrm{i}} / h_{\mathrm{p}}-$ относительная глубина; $h_{\mathrm{i}}-$ средняя глубина интервала опробования, м; $h_{\mathrm{p}}$ - мощность торфяной залежи, л

Fig. 2. Change of specific electric conductivity $\chi$ in water extracts on peat deposit depth in the ridge of HRC (I), ryam (II) and mesotrophic border (III); $h_{i} / h_{p}$ is the relative depth; $h_{i}$ is the average depth of approbation interval, $m ; h_{p}$ is the capacity of a peat deposit, $m$

Распределение изученных химических элементов в кислотных вытяжках в целом характеризуется увеличением концентраций $\mathrm{Ca}, \mathrm{Al}, \mathrm{Fe}, \mathrm{Zr}, \mathrm{Ba}$, редкоземельных элементов (РЗЭ) в нижних слоях торфов и/или минеральном грунте, максимумами в верхней и нижней частях торфяной залежи концентраций $\mathrm{K}, \mathrm{Si}, \mathrm{Pb}$, Ti (максимумы Ti в олиготрофных экосистемах отмечены в верхней части, в мезотрофной - в придонном слое торфа), а также максимумами содержаний $\mathrm{S}$ и $\mathrm{Zn}$ в разных интер- 
валах глубин (табл. 1). При этом необходимо отметить существенные вариации распределений по глубине в разных внутриболотных экосистемах. Например, максимум содержания Са в гряде ГМК (30765 мг/кг) отмечен в минеральном грунте (глина), в ряме (24223 мг/кг) - в придонном слое на относительной глубине $h_{i} / h_{p}=0,84\left(h_{i}\right.$ - средняя глубина интервала опробования, м; $h_{p}-$ мощность торфяной залежи, м). Наибольшее содержание Si закономерно отмечено в пробе суглинка, отобранной на мезотрофной окраине (3781 мг/кг), но в гряде ГМК - в нижних слоях торфа на относительной глубине $h_{i} / h_{p}=0,90$ (550 мг/кг). Максимальные концентрации $\mathrm{Al}$, как и $\mathrm{Si}$, отмечены в суглинке на мезотрофной окраине (10475 мг/кг), а в гря- де ГМК и ряме - на относительных глубинах 0,90 (5842 мг/кг) и 0,97 (3791 мг/кг), соответственно.

С учетом указанных выше фактов, в целом совпадающих с данными, полученными в марте 2017 и 2018 гг. на этих же участках, можно предположить, что ключевым фактором распределения химических элементов по глубине торфяной залежи являются, прежде всего, внутриболотные биогеохимические процессы. Последние одновременно регулируются условиями выноса и аккумуляции веществ и определяют интенсивность водообмена (за счет коэффициентов фильтрации $[7,21,22])$. Влияние атмосферных поступлений на поверхность болота, в том числе антропогенного происхождения, безусловно, также имеет место [23, 24].

Таблица 1. Физико-химические и геохимические показатели водных и кислотных вытяжек из торфов восточной части Васюганского болота 9 ноября 2018 г.

Table 1. Physical, chemical and geochemical parameters of water and acid extracts from peats of east part of the Vasyugan swamp on 9 November, 2018

\begin{tabular}{|c|c|c|c|c|c|c|c|c|c|c|c|c|c|c|c|c|c|c|c|}
\hline No & & & Интервал, м & $\mathrm{pH}$ & & $\mathrm{Ca}$ & $\mathrm{K}$ & S & $\mathrm{P}$ & $\mathrm{Si}$ & $\mathrm{Al}$ & $\mathrm{Fe}$ & $\mathrm{Ti}$ & $\mathrm{Zn}$ & $\mathrm{Y}$ & $\mathrm{Zr}$ & $\mathrm{Ba}$ & $\mathrm{La}$ & $\mathrm{Pb}$ \\
\hline Jֵ- & Ecosystem & Snil & Interval, m & (units) & $\mu \mathrm{S} / \mathrm{cm}$ & & \multicolumn{13}{|c|}{$\mathrm{M \Gamma} / \mathrm{K \Gamma} / \mathrm{mg} / \mathrm{kg}$} \\
\hline 1 & $\begin{array}{l}\text { Гряда ГМК } \\
\text { HRC ridge }\end{array}$ & торф/peat & $0,0-0,25$ & 3,60 & 68,7 & 2081 & 579 & 838 & 268 & 241 & 1231 & 2065 & 20,0 & 37 & 0,65 & 0,61 & 19 & 0,94 & 10,15 \\
\hline 2 & $-/ /-$ & $-/ /-$ & $0,25-0,50$ & 3,48 & 64,9 & 2564 & 104 & 1666 & 346 & 244 & 1532 & 1585 & 25,5 & 33 & 1,02 & 0,96 & 16 & 1,20 & 9,32 \\
\hline 3 & $-/ /-$ & $-/ /-$ & $0,50-0,75$ & 3,75 & 48,6 & 1463 & 64 & 993 & 258 & 187 & 531 & 690 & 10,6 & 17 & 0,26 & 0,33 & 6 & 0,31 & 2,77 \\
\hline 4 & $-/ /-$ & $-/ /-$ & $0,75-1,00$ & 3,72 & 45,1 & 1829 & 67 & 1083 & 259 & 159 & 559 & 672 & 11,8 & 16 & 0,26 & 0,27 & 6 & 0,34 & 1,52 \\
\hline 5 & $-/ /-$ & $-/ /-$ & $1,00-1,25$ & 3,70 & 45,3 & 1815 & 82 & 748 & 213 & 144 & 498 & 621 & 9,2 & 19 & 0,20 & 0,19 & 5 & 0,33 & 0,94 \\
\hline 6 & $-/ /-$ & $-1 /-$ & $1,25-1,50$ & 3,76 & 45,8 & 2579 & 91 & 618 & 190 & 169 & 624 & 685 & 9,7 & 22 & 0,21 & 0,18 & 6 & 0,42 & 0,77 \\
\hline 7 & $-/ /-$ & $-/ /-$ & $1,50-1,75$ & 3,84 & 45,7 & 3293 & 92 & 705 & 203 & 152 & 577 & 678 & 10,0 & 18 & 0,20 & 0,18 & 7 & 0,32 & 0,74 \\
\hline 8 & $-/ /-$ & $-1 /-$ & $1,75-2,00$ & 3,70 & 42,3 & 2510 & 168 & 771 & 213 & 156 & 668 & 741 & 11,3 & 71 & 0,27 & 0,26 & 8 & 0,45 & 2,01 \\
\hline 9 & $-/ /-$ & $-/ /-$ & $2,00-2,25$ & 3,69 & 57,3 & 2513 & 178 & 963 & 289 & 276 & 874 & 1035 & 14,5 & 77 & 0,41 & 0,37 & 10 & 0,67 & 4,81 \\
\hline 10 & $-/ /-$ & $-1 /-$ & $2,25-2,50$ & 3,73 & 48,3 & 2694 & 132 & 914 & 290 & 242 & 694 & 938 & 12,5 & 145 & 0,30 & 0,29 & 9 & 0,51 & 3,10 \\
\hline 11 & $-/ /-$ & $-/ /-$ & $2,50-2,75$ & 4,31 & 30,2 & 6568 & 57 & 1479 & 526 & 221 & 929 & 1315 & 14,0 & 69 & 0,40 & 0,36 & 11 & 0,49 & 0,83 \\
\hline 12 & $-/ /-$ & $-/ /-$ & $2,75-3,00$ & 4,50 & 27,7 & 9103 & 53 & 1775 & 456 & 188 & 914 & 2225 & 14,0 & 85 & 0,39 & 0,39 & 11 & 0,51 & 0,88 \\
\hline 13 & $-/ /-$ & $-/ /-$ & $, 00-3,25$ & 4,69 & 35,8 & 14433 & 51 & 1665 & 283 & 115 & 1190 & 3940 & 15,2 & 111 & 0,58 & 0,65 & 20 & 0,74 & 0,94 \\
\hline 14 & $-/ /-$ & $-1 /-$ & $3,25-3,50$ & 5,14 & 58,9 & 13409 & 322 & 941 & 413 & 550 & 5842 & 5819 & 15,8 & 36 & 7,08 & 4,94 & 65 & 8,55 & 6,81 \\
\hline 15 & $-/ /-$ & $-1 /-$ & $3,50-3,75$ & 4,81 & 29,7 & 10293 & 347 & 1110 & 331 & 438 & 4877 & 5344 & 14,6 & 79 & 5,77 & 4,11 & 52 & 6,78 & 6,39 \\
\hline 16 & $-/ /-$ & глина/clay & $3,75-4,10$ & 7,83 & 156,0 & 30765 & 640 & 402 & 270 & 518 & 4673 & 8577 & 8,4 & 16 & 9,61 & 6,90 & 69 & 11,40 & 10,43 \\
\hline 17 & pям/ryam & торф/peat & $0,00-0,25$ & 3,56 & 67,9 & 2187 & 498 & 1121 & 385 & 191 & 1532 & 2273 & 22,5 & 34 & 0,66 & 0,57 & 15 & 0,83 & 15,38 \\
\hline 18 & $-/ /-$ & $-/ /-$ & $0,25-0,50$ & 3,65 & 47,4 & 2568 & 151 & 1579 & 425 & 178 & 1583 & 1489 & 26,5 & 22 & 0,69 & 0,64 & 12 & 0,81 & 10,54 \\
\hline 19 & $-/ /-$ & $-/ /-$ & $0,50-0,75$ & 3,52 & 52,8 & 2283 & 99 & 1221 & 307 & 163 & 892 & 950 & 14,4 & 19 & 0,37 & 0,33 & 9 & 0,49 & 5,51 \\
\hline 20 & $-/ /-$ & $-1 /-$ & $0,75-1,00$ & 3,17 & 47,7 & 3046 & 75 & 1050 & 255 & 153 & 700 & 905 & 10,2 & 15 & 0,25 & 0,18 & 8 & 0,35 & 2,46 \\
\hline 21 & $-/ /-$ & $-/ /-$ & $1,00-1,25$ & 3,71 & 43,6 & 2721 & 78 & 1056 & 272 & 147 & 759 & 808 & 11,6 & 21 & 0,29 & 0,23 & 9 & 0,43 & 2,98 \\
\hline 22 & $-/ /-$ & $-/ /-$ & $, 25-1,50$ & 4,10 & 30,6 & 3771 & 50 & 1472 & 340 & 119 & 625 & 812 & 8,3 & 12 & 0,27 & 0,14 & 12 & 0,39 & 1,04 \\
\hline 23 & $-/ /-$ & $-/ /-$ & $1,50-1,75$ & 4,40 & 32,3 & 6660 & 50 & 1724 & 383 & 127 & 704 & 1488 & 9,9 & 19 & 0,30 & 0,19 & 10 & 0,37 & 1,13 \\
\hline 24 & $-/ /-$ & $-/ /-$ & $1,75-2,00$ & 4,55 & 29,9 & 8569 & 42 & 1587 & 363 & 108 & 762 & 1715 & 11,2 & 27 & 0,33 & 0,27 & 9 & 0,41 & 1,13 \\
\hline 25 & $-/ /-$ & $-/ /-$ & $2,00-2,25$ & 4,82 & 27,1 & 12305 & 35 & 1538 & 254 & 115 & 712 & 1735 & 10,9 & 16 & 0,34 & 0,27 & 10 & 0,44 & 1,14 \\
\hline 26 & $-/ /-$ & $-/ /-$ & $2,25-2,50$ & 5,30 & 31,5 & 19886 & 30 & 2202 & 321 & 128 & 757 & 2590 & 10,7 & 16 & 0,36 & 0,29 & 14 & 0,46 & 0,64 \\
\hline 27 & $-/ /-$ & $-/ /-$ & $2,50-2,75$ & 4,92 & 32,2 & 18196 & 39 & 2256 & 329 & 115 & 807 & 2517 & 11,9 & 36 & 0,40 & 0,35 & 17 & 0,46 & 1,25 \\
\hline 28 & $-/ /-$ & $-/ /-$ & $2,75-3,00$ & 5,43 & 27,2 & 21295 & 26 & 2554 & 301 & 100 & 821 & 3305 & 10,8 & 14 & 0,42 & 0,39 & 20 & 0,46 & 0,59 \\
\hline 29 & $-/ /-$ & $-1 /-$ & $3,00-3,25$ & 5,69 & 37,6 & 24223 & 73 & 2603 & 329 & 155 & 1130 & 4664 & 14,6 & 16 & 0,99 & 0,82 & 26 & 1,11 & 1,16 \\
\hline 30 & $-/ /-$ & $-/ /-$ & $3,25-3,50$ & 5,64 & 30,3 & 20691 & 34 & 2433 & 296 & 127 & 732 & 5118 & 10,3 & 9 & 0,77 & 0,61 & 31 & 0,66 & 0,59 \\
\hline 31 & $-/ /-$ & $-/ /-$ & $3,50-3,70$ & 5,63 & 60,8 & 10104 & 812 & 1021 & 273 & 715 & 3791 & 4306 & 14,1 & 25 & 8,12 & 5,35 & 45 & 8,27 & 6,57 \\
\hline 32 & $-/ /-$ & глина/clay & $3,70-3,95$ & 7,58 & 140,4 & 10723 & 799 & 373 & 261 & 758 & 3747 & 7183 & 8,7 & 25 & 8,98 & 7,02 & 47 & 11,29 & 9,82 \\
\hline 33 & $\begin{array}{c}\text { окраина } \\
\text { border }\end{array}$ & торф/peat & $0,00-0,25$ & 4,01 & 30,9 & 4433 & 183 & 1554 & 643 & 129 & 1005 & 1609 & 11,4 & 31 & 0,49 & 0,27 & 15 & 0,60 & 5,81 \\
\hline 34 & $-/ /-$ & $-/ /-$ & $0,25-0,50$ & 4,49 & 21,7 & 9539 & 43 & 1592 & 646 & 143 & 1586 & 2860 & 14,1 & 16 & 0,83 & 0,48 & 14 & 0,77 & 1,60 \\
\hline 35 & $-/ /-$ & $-/ /-$ & $0,50-0,75$ & 5,06 & 20,8 & 13519 & 26 & 1774 & 485 & 137 & 1416 & 3378 & 16,9 & 15 & 0,64 & 0,47 & 15 & 0,60 & 0,94 \\
\hline 36 & $-/ /-$ & $-/ /-$ & $0,75-1,00$ & 5,26 & 20,1 & 18172 & 18 & 1536 & 377 & 121 & 1308 & 4386 & 17,8 & 15 & 0,57 & 0,61 & 21 & 0,57 & 0,81 \\
\hline 37 & $-1 /-$ & $-/ /-$ & $1,00-1,25$ & 5,27 & 23,7 & 21458 & 17 & 1897 & 365 & 139 & 1231 & 5175 & 19,1 & 12 & 0,56 & 0,76 & 25 & 0,57 & 0,73 \\
\hline 38 & $-/ /-$ & $-/ /-$ & $1,25-1,50$ & 5,43 & 23,5 & 23281 & 16 & 1695 & 318 & 151 & 1001 & 6056 & 15,7 & 8 & 0,50 & 0,65 & 26 & 0,50 & 0,62 \\
\hline 39 & $-1 /-$ & $-/ /-$ & $1,50-1,60$ & 5,60 & 70,3 & 26524 & 134 & 1863 & 484 & 1313 & 4562 & 8363 & 23,3 & 10 & 3,56 & 4,05 & 46 & 4,22 & 2,64 \\
\hline 40 & $-/ /-$ & $\begin{array}{c}\text { суглинок } \\
\text { loam }\end{array}$ & $1,60-1,75$ & 6,10 & 51,2 & 13741 & 598 & 447 & 480 & 3781 & 10475 & 10652 & 15,0 & 25 & 9,25 & 6,63 & 85 & 11,28 & 8,38 \\
\hline
\end{tabular}


Таблица 2. Микробиологические показатели вытяжек из торфов восточной части Васюганского болота 9 ноября 2018 г.

Table 2. $\quad$ Microbiological parameters of extracts from peats of east part of the Vasyugan swamp on 9 November, 2018

\begin{tabular}{|c|c|c|c|c|c|c|c|c|c|c|c|}
\hline \multirow[b]{2}{*}{ № } & \multicolumn{11}{|c|}{ Бактерии, кл/мл/Bacteria, cells/ml } \\
\hline & $\begin{array}{l}\text { денитрифи- } \\
\text { цирующие } \\
\text { deitrificans }\end{array}$ & \begin{tabular}{|c} 
нитрифи- \\
цирую- \\
щие \\
nitrificans
\end{tabular} & $\begin{array}{c}\text { аммонифи- } \\
\text { цирующие } \\
\mathrm{NH}_{4}^{+} \text {for- } \\
\text { ming }\end{array}$ & $\begin{array}{c}\text { нефтеоки- } \\
\text { сляющие } \\
\text { oil oxidi- } \\
\text { zing }\end{array}$ & $\begin{array}{c}\text { олиго- } \\
\text { трофные } \\
\text { oligo- } \\
\text { trophic }\end{array}$ & $\begin{array}{c}\text { образующие } \\
\text { гидроксиды Fe } \\
\text { forming Fe } \\
\text { hydroxides }\end{array}$ & \begin{tabular}{|} 
Fе-окисля- \\
ющие \\
Fe-oxidi- \\
zing
\end{tabular} & $\begin{array}{c}\text { сульфатвосста- } \\
\text { навливающие } \\
\text { sulfates } \\
\text { restoring }\end{array}$ & $\begin{array}{c}\text { Thioba- } \\
\text { cillus } \\
\text { thioparus }\end{array}$ & $\begin{array}{l}\text { Thiobacillus } \\
\text { intermedius }\end{array}$ & $\begin{array}{c}\text { Thiobacillus } \\
\text { novellus }\end{array}$ \\
\hline 1 & 0 & 0 & 1000 & 14000 & 77000 & 66000 & 18000 & 10000 & 0 & 1840000 & 832000 \\
\hline 2 & 0 & 1000 & 1000 & 0 & 42000 & 410000 & 206000 & 100000 & 0 & 313000 & 212000 \\
\hline 3 & 1000 & 10000 & 1000 & 24000 & 167000 & 40000 & 24000 & 0 & 0 & 1620000 & 733000 \\
\hline 4 & 1000 & 1000 & 10000 & 8000 & 426000 & 60000 & 7000 & 0 & 0 & 1100000 & 619000 \\
\hline 5 & 10000 & 100000 & 1000000 & 5000 & 53000 & 118000 & 0 & 100000 & 57000 & 322000 & 880000 \\
\hline 6 & 10000 & 0 & 100000 & 60000 & 1500000 & 176000 & 13000 & 0 & 0 & 2960000 & 1440000 \\
\hline 7 & 10000 & 0 & 100000 & 0 & 592000 & 97000 & 203000 & 10000 & 14000 & 1632000 & 320000 \\
\hline 8 & 10000 & 100000 & 10000 & 0 & 8000 & 61000 & 118000 & 10000 & 0 & 73000 & 42000 \\
\hline 9 & 1000 & 10000 & 100000 & 16000 & 103000 & 17000 & 6000 & 1000 & 22000 & 146000 & 40000 \\
\hline 10 & 0 & 100000 & 10000 & 0 & 305000 & 90000 & 0 & 0 & 0 & 69000 & 62000 \\
\hline 11 & 1000000 & 100000 & 100000 & 0 & 810000 & 120000 & 6000 & 0 & 0 & 2240000 & 1015000 \\
\hline 12 & 10000 & 100000 & 1000000 & 0 & 853000 & 80000 & 155000 & 0 & 0 & 1320000 & 1410000 \\
\hline 13 & 1000 & 10000 & 1000 & 14000 & 1069000 & 360000 & 3200000 & 100000 & 0 & 5160000 & 1750000 \\
\hline 14 & 10000 & 100000 & 1000 & 0 & 958000 & 63000 & 110000 & 1000 & 0 & 1722000 & 1600000 \\
\hline 15 & 0 & 1000 & 1000 & 0 & 1960000 & 157000 & 390000 & 1000 & 650000 & 9100000 & 4230000 \\
\hline 16 & 1000 & 100000 & 10000 & 19000 & 1922000 & 140000 & 20000 & 10000 & 0 & 4860000 & 3760000 \\
\hline 17 & 10000 & 100000 & 100000 & 20000 & 145000 & 5000 & 0 & 1000 & 40000 & 82000 & 1920000 \\
\hline 18 & 0 & 0 & 0 & 0 & 149000 & 21000 & 22000 & 1000 & 0 & 4800000 & 1040000 \\
\hline 19 & 0 & 0 & 0 & 1400000 & 460000 & 105000 & 13000 & 10000 & 30000 & 1800000 & 2280000 \\
\hline 20 & 0 & 0 & 0 & 96000 & 96000 & 28000 & 34000 & 1000 & 0 & 130000 & 123000 \\
\hline 21 & 10000 & 1000 & 10000 & 93000 & 1105000 & 21000 & 11000 & 0 & 0 & 440000 & 272000 \\
\hline 22 & 0 & 0 & 1000 & 1260000 & 1310000 & 17000 & 33000 & 10000 & 0 & 564000 & 232000 \\
\hline 23 & 1000 & 0 & 10000 & 362000 & 366000 & 332000 & 65000 & 1000 & 18000 & 213000 & 816000 \\
\hline 24 & 0 & 0 & 0 & 390000 & 1321000 & 88000 & 16000 & 1000 & 0 & 177000 & 134000 \\
\hline 25 & 1000 & 0 & 0 & 410000 & 580000 & 125000 & 41000 & 1000 & 0 & 860000 & 275000 \\
\hline 26 & 10000 & 1000 & 1000 & 12000 & 1320000 & 152000 & 5500000 & 100000 & 34000 & 2810000 & 1325000 \\
\hline 27 & 0 & 0 & 0 & 26000 & 440000 & 70000 & 21000 & 10000 & 0 & 482000 & 2240000 \\
\hline 28 & 100000 & 0 & 100000 & 80000 & 142000 & 0 & 1056000 & 0 & 0 & 1344000 & 690000 \\
\hline 29 & 10000 & 0 & 10000 & 0 & 1200000 & 0 & 0 & 0 & 0 & 1200000 & 2100000 \\
\hline 30 & 100000 & 0 & 1000000 & 120000 & 8100000 & 0 & 380000 & 0 & 0 & 981000 & 798000 \\
\hline 31 & 10000 & 0 & 100000 & 80000 & 1150000 & 58000 & 70000 & 0 & 0 & 199000 & 93000 \\
\hline 32 & 1000 & 10000 & 100000 & 30000 & 540000 & 27000 & 63000 & 1000 & 21000 & 1221000 & 1510000 \\
\hline 33 & 1000 & 1000 & 10000 & 16000 & 532000 & 0 & 22000 & 10000 & 0 & 218000 & 244000 \\
\hline 34 & 10000 & 0 & 100000 & 200000 & 2150000 & 259000 & 18000 & 1000 & 0 & 770000 & 530000 \\
\hline 35 & 1000 & 1000 & 10000 & 0 & 391000 & 210000 & 50000 & 0 & 0 & 1054000 & 1122000 \\
\hline 36 & 10000 & 10000 & 10000 & 0 & 422000 & 58000 & 51000 & 0 & 0 & 322000 & 473000 \\
\hline 37 & 10000 & 10000 & 100000 & 0 & 1040000 & 200000 & 716000 & 10000 & 0 & 4400000 & 2100000 \\
\hline 38 & 1000 & 1000 & 10000 & 20000 & 890000 & 320000 & 2704000 & 10000 & 180000 & 1500000 & 2640000 \\
\hline 39 & 0 & 0 & 1000 & 0 & 2220000 & 235000 & 6340000 & 10000 & 0 & 1520000 & 1322000 \\
\hline 40 & 1000 & 0 & 0 & 6000 & 3000000 & 268000 & 4300000 & 1000000 & 0 & 1244000 & 1359000 \\
\hline
\end{tabular}

Но его роль, судя по сильной изменчивости концентраций изученных веществ в деятельном горизонте торфяной залежи (табл. 1), в условиях восточной части Васюганского болота преувеличена.

Микробиологический анализ позволил выявить различные физиологические группы микроорганизмов, среди которых преобладают тионовые бактерии (Thiobacillus novellus и Thiobacillus intermedius), железобактерии, окисляющие восстановленные соединения железа, и гетеротрофные олиготрофные бактерии (рис. 3, табл. 2). Все перечисленные группы микроорганизмов хорошо приспособлены к анаэробным условиям, низким значениям $\mathrm{pH}$ и температуры болотных вод. Количество бактерий Thiobacillus thioparus, приспособленных к нейтральной и щелочной среде, и железобактерий, образующих гидроксиды железа, значительно меньше содержаний других тионовых бактерий и гетеротрофных бактерий, окисляющих восстановленные соединения железа (далее используется сокращение «Fе-окисляющие бактерии»).

Однако нельзя не отметить относительно равномерное распределение содержаний бактерий, образующих гидроксиды железа, по глубине торфяной залежи всех трех изученных участков, что указывает на постоянно наблюдаемую возможность участия микрооорганизмов в выведении малорастворимых соединений железа из болотных вод. Нефтеокисляющие бактерии в значительных количествах отмечены преимущественно в пробах торфов ряма. Среди микроорганизмов цикла азота наиболее представлены аммонифицирующие бактерии. Прочие группы микроорганизмов, более требовательных к содержанию кислорода, обнаружены в целом в заметно меньших количествах (табл. 2). 
Таблица 3. Статистически значимые коэффициенты корреляции между физико-химическили, геохилическили и микробиологическими показателями торфов гряды ГMК, ряма и мезотрофной окраины

Table 3. Statistically significant factors of correlation between physical and chemical, geochemical and microbiological parameters of peats of the HRC ridge, ryam and mesotrophivc border

\begin{tabular}{|c|c|c|c|c|c|c|c|c|}
\hline Показатель/Indicator & $\begin{array}{c}\text { Нитрифици- } \\
\text { рующие бак- } \\
\text { терии } \\
\text { Nitrificans } \\
\text { bacteria }\end{array}$ & $\begin{array}{c}\text { Аммонифи- } \\
\text { цирующие } \\
\text { бактерии } \\
\mathrm{NH}_{4}^{+} \text {forming } \\
\text { bacteria }\end{array}$ & $\begin{array}{l}\text { Олиготроф- } \\
\text { ные бакте- } \\
\text { рии } \\
\text { Oligotrophic } \\
\text { bacteria }\end{array}$ & $\begin{array}{c}\text { Железобактерии, } \\
\text { образующие ги- } \\
\text { дроксиды Fe } \\
\text { Fe-hydroxodes } \\
\text { forming bacteria }\end{array}$ & \begin{tabular}{|c|} 
Fе-окисля- \\
ющие бак- \\
терии \\
Fe-oxidizing \\
bacteria
\end{tabular} & \begin{tabular}{|} 
Thioba- \\
cillus \\
thioparus
\end{tabular} & $\begin{array}{l}\text { Thiobacil- } \\
\text { lus inter- } \\
\text { medius }\end{array}$ & $\begin{array}{c}\text { Thioba- } \\
\text { cillus } \\
\text { novellus }\end{array}$ \\
\hline $\begin{array}{l}\text { Денитрифицирующие бактерии } \\
\text { Denitrificans bacteria }\end{array}$ & 0,34 & - & - & - & - & - & - & - \\
\hline $\begin{array}{l}\text { Аммонифицирующие бактерии } \\
\mathrm{NH}_{4}{ }^{+} \text {forming bacteria }\end{array}$ & 0,37 & - & - & - & - & - & - & - \\
\hline $\begin{array}{l}\text { Олиготрофные бактерии } \\
\text { Oligotrophic bacteria }\end{array}$ & - & 0,46 & - & - & - & - & - & - \\
\hline $\begin{array}{l}\text { Fe-окисляющие бактерии } \\
\text { Fe-oxidizing bacteria }\end{array}$ & - & - & - & 0,39 & - & - & - & - \\
\hline $\begin{array}{l}\text { Сульфатвосстанавливающие бактерии } \\
\text { Sulfates restoring bacteria }\end{array}$ & - & - & - & 0,48 & 0,43 & - & - & - \\
\hline Thiobacillus intermedius & - & - & - & - & - & 0,67 & - & - \\
\hline Thiobacillus novellus & - & - & - & - & - & 0,67 & 0,70 & - \\
\hline $\mathrm{pH}$ & - & - & 0,45 & - & 0,44 & - & - & 0,33 \\
\hline $\mathrm{Ca}$ & - & - & 0,40 & - & 0,57 & - & - & 0,40 \\
\hline $\mathrm{S}$ & $-0,32$ & - & 0,37 & - & 0,35 & - & - & - \\
\hline $\mathrm{Al}$ & - & - & - & - & - & 0,42 & 0,37 & 0,38 \\
\hline $\mathrm{Fe}$ & - & - & 0,43 & - & 0,53 & - & 0,32 & 0,51 \\
\hline $\mathrm{Mn}$ & - & - & - & - & 0,45 & - & - & 0,35 \\
\hline $\mathrm{Cu}$ & - & - & - & - & 0,35 & 0,37 & 0,38 & 0,44 \\
\hline $\mathrm{Ba}$ & - & - & 0,35 & - & - & 0,40 & 0,36 & 0,45 \\
\hline $\mathrm{La}$ & - & - & - & - & - & 0,40 & - & - \\
\hline
\end{tabular}

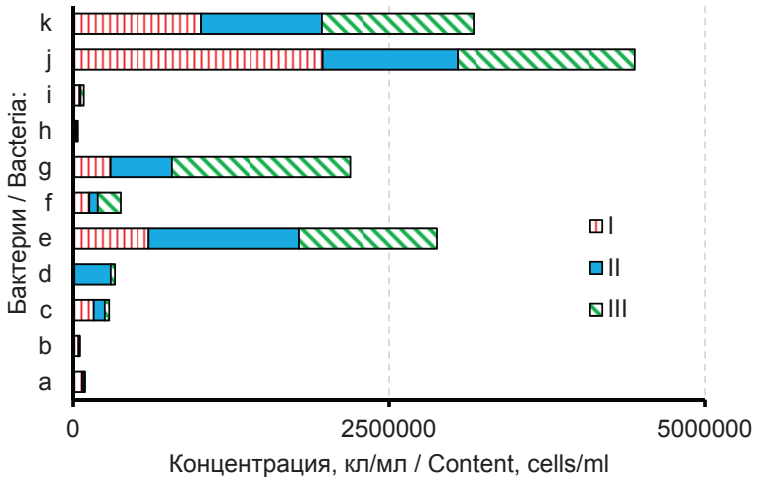

Рис. 3. Средние значения содержаний различных физиологических групп микроорганизлов в вытяжках из торфов, отобранных в гряде ГМК (I), ряме (II) и на мезотрофной окраине (III); бактерии: $a$ - денитрифицирующие; $b$ нитрифицирующие; с - алмонифицирующие; $d$ - неф теокисляющие; $е$ - олиготрофные; $f$ - образующие гидроксиды железа; g- окисляющие соединенияжелеза; $h$ - суль фатвосстанавливающие; $i$ - Thiobacillus thioparus; $j$ Thiobacillus intermedius; $k$ - Thiobacillus novellus

Fig. 3. Average values of contents of microorganisms physiological groups in peat extracts in the ridge of the HRC (I), ryam (II) and mesotrophic border (III); bacteria: $a$ - denitrificans; $b$ nitrificans; $c$ - ammonium forming; $d$-oil oxidizing; $e$ - oligotrophic; $f$ - Fe-hydroxodes forming; $g$ - Fe-oxidizing; $h$ Sulfates restoring; $i$ - Thiobacillus thioparus; $j$ - Thiobacillus intermedius; $k$ - Thiobacillus novellus

Между рядом микробиологических и геохимических показателей при уровне значимости $5 \%$ выявлены статистически значимые связи, причем преимущественно прямые. В частности, такие свя- зи установлены между величиной $\mathrm{pH}$ водных вытяжек, концентрациями $\mathrm{Ca}, \mathrm{Fe}, \mathrm{S}$ в кислотных вытяжках и содержанием в образцах торфов олиготрофных, тионовых бактерий и Fе-окисляющих бактерий (табл. 3). Возможно, это объясняется как использованием разными физиологическими группами микроорганизмов одних и тех же источников вещества и энергии и/или выделением одних и тех же продуктов метаболизма и их соединений (например, тионовыми и Fе-окисляющими бактериями, сульфатвосстанавливающими и бактериями, образующими гидроксиды железа), так и включением в анализ микроорганизмов из разных групп. В частности, в составе олиготрофных микроорганизмов могут присутствовать, с одной стороны, некоторые виды тионовых бактерий и железобактерий, а с другой стороны - аммонифицирующие бактерии (в последнем случае коэффициент корреляции $r=0,46)$. Обратная связь выявлена между содержаниями серы и нитрифицирующих бактерий, что объясняется взаимосвязанным ухудшением аэробных условий в торфяной залежи и выведением из раствора сульфидов металлов [10].

Безусловно, влияние геохимических и гидрологических факторов (содержания веществ - источников энергии и строительного материала клеток, содержания токсичных продуктов метаболизма, время и условия их контакта с микроорганизмами в условиях преобладания адвективного в деятельном горизонте торфяной залежи, диффузионного переноса в основной части инертного го- 
ризонта, либо их почти полного отсутствия в ряде случаев в нижних слоях торфяной залежи) является в целом комплексом стохастических процессов, результат действия которого можно оценить только в вероятностном смысле даже при наличии максимально полной информации, которая обычно отсутствует. Кроме того, полученные в рассматриваемой работе результаты характеризуют потенциальные, а не фактические условия функционирования болотной микрофлоры. Поэтому не представляется возможным абсолютно однозначный и точный прогноз распределения содержаний химических элементов в кислотных вытяжках из торфов в зависимости от содержания микроорганизмов и наоборот. Тем не менее в ряде случаев удалось выявить прогностические зависимости, отражающие наиболее общие взаимосвязи между микробиологическими и геохимическими показателями.

Так, была установлена зависимость для торфов

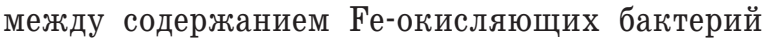
(Febac., тыс. кл/мл), pН водной вытяжки и кон-

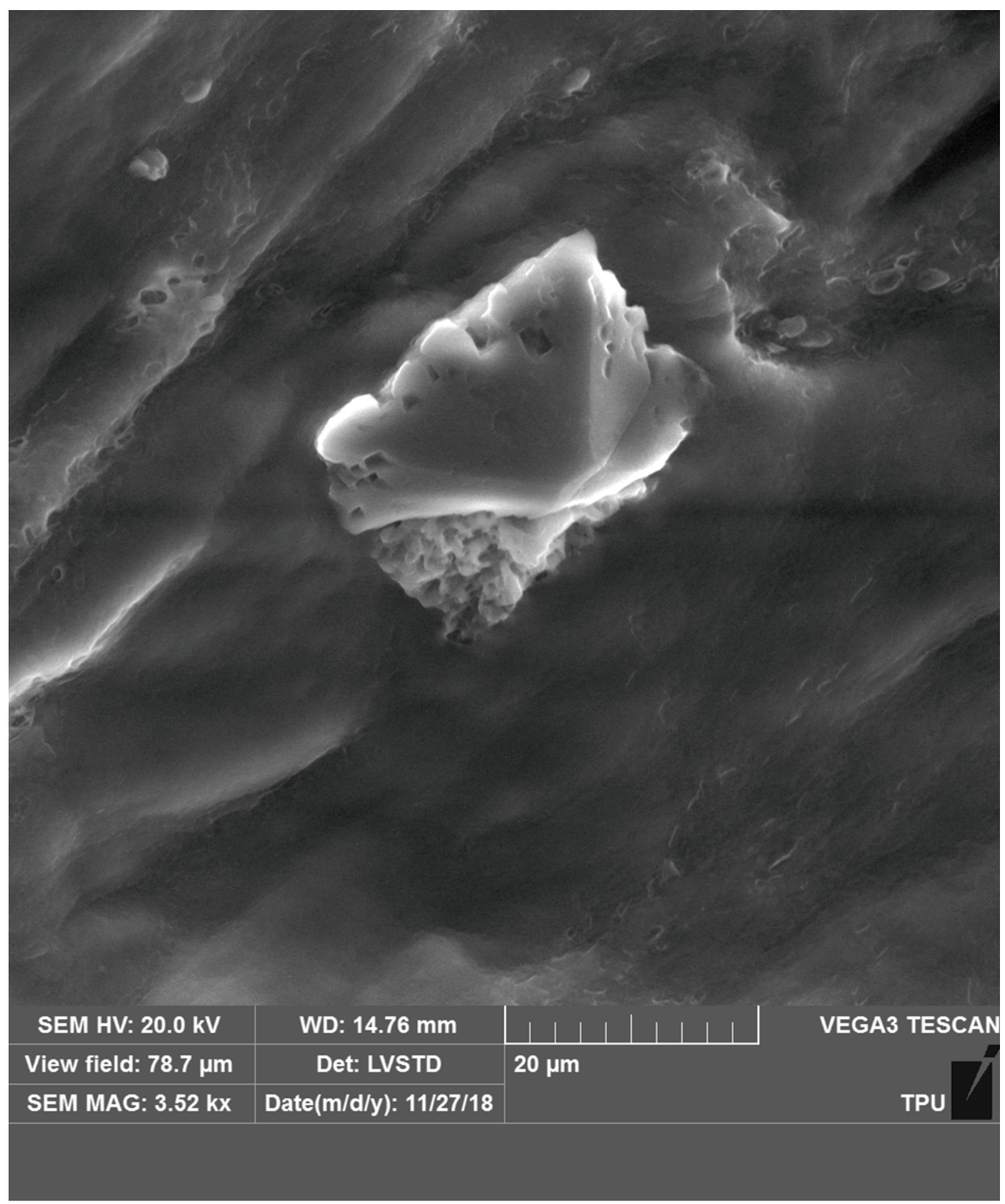

Pис. 4. Снимок минерального включения в торф в гряде, интервал 0,00-0,25 м; результаты полуколичественного спектрального анализа: 1) непосредственно включение: C - 38,59\%; O-48,13\%; P- 0,39\%; S- 0,28\%; $\mathrm{Ca}-10,68 \% ; \mathrm{Fe}-1,44 \% ; \mathrm{Na}-0,49 \% ; 2)$ фон (на снилке ниже включения) - C-58,42\%; O-37,32\%; P-0,63\%; S-0,46\%; $\mathrm{Ca}-0,79 \% ; \mathrm{Fe}-2,07 \% ; \mathrm{K}-0,32 \%$

Fig. 4. Picture of mineral inclusion in peat in a ridge, an interval of 0,00-0,25 $\mathrm{m}$; results of half-quantitative spectral analysis: 1$)$ inclusion is direct: $\mathrm{C}-38,59 \% ; \mathrm{O}-48,13 \% ; \mathrm{P}-0,39 \% ; \mathrm{S}-0,28 \% ; \mathrm{Ca}-10,68 \% ; \mathrm{Fe}-1,44 \% ; \mathrm{Na}-0,49 \% ; 2$ ) background (it is shown below inclusion in picture) $-\mathrm{C}-58,42 \% ; \mathrm{O}-37,32 \% ; \mathrm{P}-0,63 \% ; \mathrm{S}-0,46 \% ; \mathrm{Ca}-0,79 \% ; \mathrm{Fe}-2,07 \% ; \mathrm{K}-0,32 \%$ 
центрациями $\mathrm{Ca}, \mathrm{S}, \mathrm{Fe}$ в кислотных вытяжках (квадрат корреляционного отношения $R^{2}=0,94$ ):

$$
\begin{gathered}
{[\mathrm{Ca}]=(-21151,108 \pm 2999,061)+} \\
+(4873,022 \pm 961,206) \mathrm{pH}+(4,279 \pm 0,908)[\mathrm{S}]+ \\
+(0,974 \pm 0,276)[\mathrm{Fe}]+(0,742 \pm 0,276)[\mathrm{Fe} \mathrm{bac}] .
\end{gathered}
$$

Не совсем очевидна роль кальция в развитии

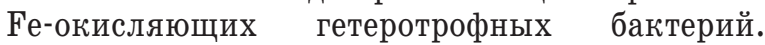
Но можно предположить, что он является составляющей продуктов их метаболизма. Это в общих чертах подтверждается результатами электронной микроскопии минеральных включений, образовавшихся уже в лабораторных условиях в пробе болотной воды, которая была отобрана в гряде в интервале глубин $0,2-0,4$ м от средней поверхности болота. Болотная вода высевалась на агаризованную среду Калиненко. После 10 дней в чашке Петри сформировались твердые включения, одно из которых представлено на рис. 4 .

Состав исходной болотной воды характеризовался следующими показателями: $\mathrm{pH} 4,45$; сумма главных ионов 9,6 мг/дм ${ }^{3}$; концентрация $\mathrm{Fe}$ $0,695 \mathrm{мг} /$ дм $^{3} ;$ бихроматная окисляемость $85,8 \mathrm{мгO} /$ дм $^{3}$; содержание сульфатвосстанавливающих бактерий 1 млн кл/мл, окисляющих соединения железа - 9150 кл/мл, образующих гидроксиды железа - 980 кл/мл, общее содержание тионовых бактерий - 3190 кл/мл. Химический состав кислотных вытяжек из проб торфа, отобранных в диапазонах глубин 0,00-0,25 и 0,25-0,50 м, соответствует данным образцов № 1 и 2 в табл. 1 . В целом вероятность образования малорастворимых соединений кальция (предположительно кальцит с включениями гидроксидов железа, рис. 4) повышается при улучшении условий существования микрофлоры, что в природе может наблюдаться в относительно маловодные годы и приводить к формированию в торфяной залежи минеральных включений, ранее выявленных на исследуемой части васюганского болота [25]. Также можно предположить, что деятельность болотной микрофлоры при определенной интенсивности водообмена может приводить к чередованию фрагментов торфяной залежи с достаточно резко отличающимися содержаниями питательного субстрата и/или токсичных продуктов метаболизма. Если этот процесс слабо дифференцирован, то обычно формируются евтрофные и мезотрофные экосистемы (при избыточном накоплении продуктов мета-

\section{СПИСОК ЛИТЕРАТУРЫ}

1. Shotyk W. Review of the inorganic geochemistry of peats and peatland waters // Earth-Science Reviews. - 1988. - № 25. P. 95-176. DOI: 10.1016/0012-8252(88)90067-0.

2. Steinmann P., Shotyk W. Geochemistry, mineralogy, and geochemical mass balance on major elements in two peat bog profiles (Jura Mountains, Switzerland) // Chemical Geology. - 1997. № 138. - P. 25-53. DOI: 10.1016/S0009-2541(96)00171-4.

3. Ecosystem recovery and natural degradation of spilled crude oil in peat bog ecosystems of West Siberia / W. Bleuten, E. Lapshina, болизма) либо мезотрофные и олиготрофные рямы (при их недостаточной концентрации), а если больше рассредоточен в двухмерном горизонтальноориентированном пространстве - олиготрофные грядово-мочажинные комплексы [14]. Но практически во всех случаях это приводит к дискретному характеру распределения химических элементов (рис. 1,2 , табл. 1) и малорастворимых (в наблюдаемых геохимических условиях) минеральных включений в торфа [25-28].

\section{Заключение}

В результате исследования получены следующие выводы:

1) болотная микрофлора является важным фактором распределения химических элементов по глубине торфяной залежи в различных внутриболотных экосистемах восточной части Васюганского болота; вероятность накопления в торфах малорастворимых соединений кальция, железа и РЗЭ возрастает по мере усиления анаэробных условий развития болотной микрофлоры, определяющих увеличение $\mathrm{pH}$ болотной среды до 7,8 и выше, что приводит к смещению карбонатного равновесия и выпадению малорастворимых соединений кальция (вопрос об идентификации кальцита или аморфных форм карбоната кальция и условиях их трансформации в торфяной залежи остается открытым);

2) возможность выведения из раствора гидроксидов железа является характерной особенностью геохимии торфяных болот на фоне незначительной, но постоянно наблюдаемой активности железобактерий, образующих гидроксиды железа, что подтверждается результатами анализа состава минеральных включений в торфа $[6,25]$

3) вследствие сорбционных процессов на частицах гидроксида железа (и малорастворимых соединений кальция в нижних слоях торфяной залежи) происходит осаждение гидроокислов, фосфатов и карбонатов (возможно - сульфатов и сульфидов) ряда микроэлементов, включая РЗЭ, что подтверждается как расчетами осаждения и сорбции [7], так и данными о распределении микрофлоры по глубине торфяной залежи.

Работа выполнена при финансовой поддержке грантов РФФИ № 18-55-80015, 17-05-00042.

W. Ivens, V. Shinkarenko, E. Wiersma // International Peat Journal. - 1999. - № 9. - P. 73-82.

4. Eurasian Mires of the Southern Taiga Belt: Modern Features and Response to Holocene Palaeoclimate / T. Minayeva, W. Bleuten, A. Sirin, E.D. Lapshina // Wetlands and Natural Resource Management. Ecological Studies. V. 190 / Eds. J.T.A. Verhoeven, B. Beltman, R. Bobbink, D.F. Whigham. - Berlin; Heidelberg: Springer-Verlag, 2006. - P. 315-341.

5. Modes of occurrence of rare earth elements in peat from Western Siberia / S.I. Arbuzov, S.G. Maslov, R.B. Finkelman, 
A.M. Mezhibor, S.S. Ilenok, M.G. Blokhin, E.V. Peregudina // Journal of Geochemical Exploration. - 2017. - V. 10. - P. 1-22. URL: https://doi.org/10.1016/j.gexplo.2017.10.012 (дата обращения 23.08.2019).

6. Изменения химического состава кислотных вытяжек по глубине торфяной залежи внутриболотных экосистем Васюганского болота (Вападная Сибирь) / О.Г. Савичев, А.К. Мазуров, М.А. Рудмин, А.А. Хващевская, А.Б. Даулетова // Известия Томского политехнического университета. Инжиниринг георесурсов. - 2018. - Т. 329. - № 9. - С. 101-116.

7. Mechanisms of Accumulation of Chemical Elements in a Peat Deposit in the Eastern Part of Vasyugan Swamp (West Siberia) / O.G. Savichev, A.K. Mazurov, M.A. Rudmin, N.E. Shakhova, V.I. Sergienko, I.P. Semiletov // Doklady Earth Sciences. - 2019. V. 486. - P. 1. - P. 568-570. D0I: 10.1134/S1028334X19050258.

8. Крайнов С.Р., Рыженко Б.Н., Швец В.М. Геохимия подземных вод. Теоретические, прикладные и экологические аспекты / отв. ред Н.П. Лавёров. - М.: Наука, 2004. - 677 с.

9. Shvartsev S.L. Geochemistry of fresh Groundwater in the Main Landscape Zones of the Earth // Geochemistry International. 2008. - V. 46. - № 13. - P. 1285-1398.

10. Formation of sphalerite (ZnS) deposits in natural biofilms of sulfate-reducing bacteria / M. Labrenz, G.K. Druschel, T. ThomsenEbert, B. Gilbert, S.A. Welch, K.M. Kemner, G.A. Logan, R.E. Summons, G. Stasio, P.L. Bond, B. Lai, S.D. Kelly, J.F. Banfield // Science. - 2000. - № 290. - P. 1744-1747.

11. Solubility, Mobility, and Bioaccumulation of Trace Elements: Abiotic Processes in the Rhizosphere / B. Robinson, N. Bolan, S. Mahimairaja, B. Clothier // Trace elements in the environment: biogeochemistry, biotechnology, and bioremediation / ed. by M.N.V. Prasad, Ravi Naidu, Kenneth S. Sajwan. - New York, USA: Taylor \& Francis Group, 2006. - P. 97-110.

12. Geochemistry of carbonatic/sulphatic soils in the southern Angara region, Russia / Yu.N. Vodyanitskii, N.D. Kiseleva, 0.G. Lopatovskaya, A.T. Savichev // Annals of agrarian science. 2016. - № 14. - P. 140-151. URL: http://dx.doi.org/10.1016/ j.aasci.2016.05.016 (дата обращения 23.08.2019).

13. Научно-исследовательский полигон «Васюганье». Программа научной экскурсии / Л.И. Инишева, Т.В. Дементьева, Е.А. Головацкая, Е.В. Порохина. - Томск: ЦНТИ, 2003. - 88 с.

14. Гидрогеохимические условия формирования олиготрофных болотных экосистем / О.Г. Савичев, А.К. Мазуров, И.П. Семилетов, В.А. Базанов, Н.В. Гусева, А.А. Хващевская, Н.Г. Наливайко // Известия РАН. Серия географическая. - 2016. № 5. - C. 60-69. URL: http://dx.doi.org/10.15356/ 0373-2444-2016-5-60-69 (дата обращения 23.08.2019).

15. ГОСТ 17644-83. Торф. Методы отбора проб из залежи и обработки их для лабораторных испытаний. - М.: Изд-во стандартов, 1983. - 12 c.
16. Экология микроорганизмов /под ред. А.И Нетрусова. - М.: AKADEMA, 2004. $-267 \mathrm{c}$.

17. Наливайко Н.Г. Микробиология воды. - Томск: Изд-во Томск. политехн. ун-та, 2009. - 139 с.

18. Савичев О.Г., Наливайко Н.Г., Трифонова Н.А. Микробиологический состав речных вод бассейна верхней и средней Оби // Сибирский экологический журнал. - 2002. - № 2. C. $173-180$.

19. РД 52.24.622-2017. Порядок проведения расчета условных фоновых концентраций химических веществ в воде водных объъектов для установления нормативов сбросов сточных вод. Дата введения 14.06.2017 г. - М.; Ростов-на-Дону: Росгидромет, ФГБУ «ГХИ», 2017. - 96 с.

20. Nash J.E., Sutcliffe J.V. River flow forecasting through conceptual models. P. I - A discussion of principles // Journal of Hydrology. - 1970. - № 10 (3). - P. 282-290.

21. Иванов К.Е. Водообмен в болотных ландшафтах. - Л.: Гидрометеоиздат, 1975 . - $280 \mathrm{c}$.

22. Seasonal dynamics of water and nutrient fluxes in an agricultural peatland / C.D. Kennedy, N. Alverson, P. Jeranyama, C. DeMoranville // Hydrological Processes. - 2018. - V. 32. - P. 698-712. DOI: 10.1002/hyp.11436.

23. Межибор А.М. Экогеохимия элементов-примесей в верховых торфах Томской области: автореф. ... канд. геол.-минерал. наук. - Томск, 2009. - 22 с.

24. Veretennikova E.E. Lead in the natural peat cores of ridge-hollow complex in the taiga zone of West Siberia // Ecological Engineering. - 2015. - V. 80. - P. 100-107.

25. Authigenic and Detrital Minerals in Peat Environment of Vasyugan Swamp, Western Siberia / M. Rudmin, A. Ruban, 0. Savichev, A. Mazurov, A. Dauletova, 0. Savinova // Minerals. 2018. - V. 500. - № 8. - P. 1-13. DOI: 10.3390/min8110500.

26. Origins of mineral matter in peat marsh and peat bog deposits, Spain / A.M. López-Buendía, M.K.G. Whateley, J. Bastida, M.M. Urquiola // International Journal of Coal Geology. 2007. - V. 71. - P. 246-262. DOI:10.1016/j.coal.2006.09.001.

27. Mineral components in a peat deposit: looking for signs of early mining and smelting activities in Silesia-Cracow region (Southern Poland) / J. Cabala, B. Smieja-Król, M. Jablonska, L. Chrost // Environmental Earth Sciences. - 2013. - № 69. P. 2559-2568. DOI: $10.1007 / \mathrm{s} 12665-012-2080-6$.

28. Comparative evaluation of the mineralogical composition of Sphagnum peat and their corresponding humic acids, and implications for understanding past dust depositions / C. Zaccone, S. Pabst, G.S. Senesi, W. Shotyk, T.M. Miano // Quaternary International. - 2013. - № 306. - P. 80-87. DOI: 10.1016/j.quaint.2013.04.017.

Поступила 26.08.2019 2.

\section{Информация об авторах}

Савичев О.Г., доктор географических наук, профессор отделения геологии Инженерной школы природных ресурсов Национального исследовательского Томского политехнического университета.

Наливайко Н.Г., кандидат геолого-минералогических наук, доцент отделения геологии Инженерной школы природных ресурсов Национального исследовательского Томского политехнического университета.

Рудмин М.A., кандидат геолого-минералогических наук, доцент Инженерной школы природных ресурсов Национального исследовательского Томского политехнического университета.

Мазуров A.א., доктор геолого-минералогических наук, профессор Инженерной школы природных ресурсов Национального исследовательского Томского политехнического университета. 


\title{
MICROBIOLOGICAL CONDITIONS OF CHEMICAL ELEMENTS DISTRIBUTION ON PEAT DEPOSIT DEPTH IN ECOSYSTEMS OF THE VASYUGAN SWAMP EAST PART (WESTERN SIBERIA)
}

\author{
Oleg G. Savichev', \\ OSavichev@mail.ru
}

\author{
Nina G. Nalivaiko', \\ biologistngn@yandex.ru \\ Maxim A. Rudmin', \\ RudminMA@tpu.ru \\ Aleksey K. Mazurov', \\ AKM@tpu.ru \\ National Research Tomsk Polytechnic University, \\ 30, Lenin avenue, Tomsk, 634050, Russia.
}

\begin{abstract}
Relevance of the research is determined by the necessity to account the interrelations between distribution of chemical elements on peat deposit depth, formation, evolution and degradation of bogs when solving a number of fundamental and applied problems of study, use and protection of bogs.

The aim of the research is the estimation of microbiological conditions of chemical elements distribution on peat deposit depth and revealing of relations between geochemical and microbiological parameters of peats in east part of the Vasyugan swamp.

Methods: methods of chemical and microbiological analysis (including MS-ICP), statistical methods.

Results and conclusions. The authors have carried out chemical, mineralogical and microbiological analysis of peats and mineral ground samples. The samples were selected on the 9 of November, 2018 in east part of the Vasyugan swamp (border of a watershed of the Klyuch and Gavrilovka rivers which are the elements of a river network ("Klyuch-Bakchar; Gavrilovka-Iksa-Chaya-Ob»; intraswamp ecological systems: the oligotrophic hollow-ridge complex, a ridge; the oligotrophic pine-dwarf-shrub-sphagnum raised bog (ryam), the mesotrophic border of an oligotrophic bog). It is shown that, first, the swamp microflora is a very important factor of chemical elements distribution on peat deposit depth in various intraswamp ecosystems in east part of the Vasyugan swamp. The probability of accumulation insoluble compounds of calcium, iron and rare earth elements in peats grows in amplification of microflora development unaerobic conditions. These factors determine increase of pH up to 7,8 and higher, that results in displacement carbonate balance and loss of insoluble calcium compounds. Second, the opportunity of iron hydroxides removing from a solution is the prominent feature of geochemistry of peat bogs on a background insignificant, but constantly observable activity of iron bacteria, which formed iron hydroxides. Thirdly, owing to sorption (and insoluble calcium compounds in the bottom layers of a peat deposit) hydrooxides, phosphates and carbonates (possibly sulfates and sulfides) of some microelements, including rare earth elements, are precipitated on iron hydrooxides.
\end{abstract}

Key words:

Microbiological conditions, distribution of chemical elements, peat deposit, Vasyugan swamp, Western Siberia.

The research was financially supported by the RFBR grant no. 18-55-80015, 17-05-00042.

\section{REFERENCES}

1. Shotyk W. Review of the inorganic geochemistry of peats and peatland waters. Earth-Science Reviews, 1988, no. 25, pp. 95-176. DOI: $10.1016 / 0012-8252(88) 90067-0$.

2. Steinmann P., Shotyk W. Geochemistry, mineralogy, and geochemical mass balance on major elements in two peat bog profiles (Jura Mountains, Switzerland). Chemical Geology, 1997, no. 138, pp. 25-53. DOI: 10.1016/S0009-2541(96)00171-4.

3. Bleuten W., Lapshina E., Ivens W., Shinkarenko V., Wiersma E. Ecosystem recovery and natural degradation of spilled crude oil in peat bog ecosystems of West Siberia. International Peat Journal, 1999, no. 9, pp. 73-82.

4. Minayeva T., Bleuten W., Sirin A., Lapshina E.D. Eurasian Mires of the Southern Taiga Belt: Modern Features and Response to Holocene Palaeoclimate. Wetlands and Natural Resource Management. Ecological Studies. Vol. 190. Eds. J.T.A. Verhoeven, B. Beltman, R. Bobbink, D.F. Whigham. Berlin, Heidelberg, Springer-Verlag, 2006. pp. 315-341.

5. Arbuzov S.I., Maslov S.G., Finkelman R.B., Mezhibor A.M., Ilenok S.S., Blokhin M.G., Peregudina E.V. Modes of occurrence of rare earth elements in peat from Western Siberia. Journal of
Geochemical Exploration, 2017, no. 10, pp. 1-22. Available at: https://doi.org/10.1016/j.gexplo.2017.10.012 (accessed $23 \mathrm{Au}$ gust 2019).

6. Savichev 0.G., Mazurov A.K., Rudmin M.A., Hvashchevskaja A.A., Dauletova A.B. Changes of the chemical composition of acid extracts on depth of the peat deposit of the Vasyuganskoye mire ecological systems (the Western Siberia). Bulletin of the Tomsk Polytechnic University. Geo Assets Engineering, 2018, vol. 329, no. 9, pp. 101-116. In Rus.

7. Savichev 0.G., Mazurov A.K., Rudmin M.A., Shakhova N.E., Sergienko V.I., Semiletov I.P. Mechanisms of Accumulation of Chemical Elements in a Peat Deposit in the Eastern Part of Vasyugan Swamp (West Siberia). Doklady Earth Sciences, 2019, vol. 486, P. 1, pp. 568-570. DOI: 10.1134/S1028334X19050258.

8. Kraynov S.R., Ryzhenko B.N., Shvets V.M. Geokhimiya podzemnykh vod: teoreticheskie, prikladnye i ekologicheskie aspekty [Geochemistry of ground waters: theoretical, applied and environmental aspects]. Moscow, Nauka Publ., 2004. 677 p.

9. Shvartsev S.L. Geochemistry of fresh Groundwater in the Main Landscape Zones of the Earth. Geochemistry International, 2008, vol. 46, no. 13, pp. 1285-1398. 
10. Labrenz M., Druschel G.K., Thomsen-Ebert T., Gilbert B., Welch S.A., Kemner K.M., Logan G.A., Summons R.E., Stasio G., Bond P.L., Lai B., Kelly S.D., Banfield J.F. Formation of sphalerite (ZnS) deposits in natural biofilms of sulfate-reducing bacteria. Science, 2000, no. 290, pp. 1744-1747.

11. Robinson B., Bolan N., Mahimairaja S., Clothier B. Solubility, Mobility, and Bioaccumulation of Trace Elements: Abiotic Processes in the Rhizosphere. Trace elements in the environment: biogeochemistry, biotechnology, and bioremediation. Eds. M.N.V. Prasad, Ravi Naidu, Kenneth S. Sajwan. New York, USA, Taylor \& Francis Group, 2006. pp. 97-110.

12. Vodyanitskii Yu.N., Kiseleva N.D., Lopatovskaya 0.G., Savichev A.T. Geochemistry of carbonatic/sulphatic soils in the southern Angara region, Russia. Annals of agrarian science, 2016, no. 14, pp. 140-151. Available at: http://dx.doi.org/ 10.1016/j.aasci.2016.05.016 (accessed 23 August 2019).

13. Inisheva L.I., Dementyeva T.V., Golovatskaya E.A., Porokhina E.V. Nauchno-issledovatelskiy poligon "Vasyuganye». Programma nauchnoy ekskursii [Scientific-research ground «Vasyugane». Program of scientific excursion]. Tomsk, TSNTI Publ., 2003. $88 \mathrm{p}$.

14. Savichev 0.G., Mazurov A.K., Semiletov I.P., Bazanov V.A., Guseva N.V., Khvashchevskaya A.A., Nalivayko N.G. Hydrogeochemical conditions of formation of oligotrophic bog ecosystems. Izvestiya Rossiiskoi Akademii Nauk. Seriya Geograficheskaya, 2016, no. 5, pp. 60-69. In Rus. Available at: http://dx.doi.org 10.15356/0373-2444-2016-5-60-69 (accessed 23 August 2019).

15. GOST 17644-83. Torf. Metody otbora pro biz zalezhi i obrabotki ikh dlya laboratornykh ispytany [SS 17644-83Peat. Methods of sampling from deposit and preparation of samples for laboratory tests]. Moscow, Izdatelstvo standartov, 1983. 12 p.

16. Ekologiya mikroorganizmov [Ecology of microorganisms]. Ed. by A.I. Netrusov. Moscow, AKADEMA Publ., 2004. 267 p.

17. Nalivayko N.G. Mikrobiologiya vody [Water microbiology]. Tomsk, Tomsk Polytecnic University Publ. house, 2009. 139 p.

18. Savichev 0.G., Nalivayko N.G., Trifonova N.A. Microbiological structure of river waters of the Upper and Middle $0 \mathrm{~b}$ river basin. Contemporary Problems of Ecology, 2002, no. 2, pp. 173-180. In Rus.

19. RD 52.24.622-2017. Poryadok provedeniya rascheta uslounykh fonovykh kontsentratsiy khimicheskikh veshchestv $v$ vode vodnykh obyektov dlya ustanovleniya normativov sbrosov stochnykh vod [Procedure for calculating the background concentrations of chemicals in the water of water bodies in order to establish standards for wastewater discharges]. Moscow, Rostov-on-Don, Rosgidromet, FGBU «SCHI» Publ., 2017. 96 p.

20. Nash J.E., Sutcliffe J.V. River flow forecasting through conceptual models. P. I. A discussion of principles. Journal of Hydrology, 1970, no. 10 (3), pp. 282-290.

21. Ivanov K.E. Vodoobmen v bolotnykh landschaftakh [Water exchange in mire landscapes]. Leningrad, Gidrometeoizdat Publ., 1975. $280 \mathrm{p}$.

22. Kennedy C.D., Alverson N., Jeranyama P., DeMoranville C. Seasonal dynamics of water and nutrient fluxes in an agricultural peatland. Hydrological Processes, 2018, vol. 32, pp. 698-712. DOI: 10.1002/hyp.11436.

23. Mezhibor A.M. Ekogeokhimiya elementov-primesey v verkhovykh torfakh Tomskoy oblasi. Avtoreferat Diss. Kand. Nauk [Ecogeochemistry of accessories elements in riding peats of the Tomsk area. Cand. Diss. Abstract]. Tomsk, 2009. 22 p.

24. Veretennikova E.E. Lead in the natural peat cores of ridge-hollow complex in the taiga zone of West Siberia. Ecological Engineering, 2015, vol. 80, pp. 100-107.

25. Rudmin M., Ruban A., Savichev 0., Mazurov A., Dauletova A., and Savinova 0. Authigenic and Detrital Minerals in Peat Environment of Vasyugan Swamp, Western Siberia. Minerals, 2018, vol. 500, no. 8, pp. 1-13. DOI: 10.3390/min8110500.

26. López-Buendía A.M., Whateley M.K.G., Bastida J., Urquiola M.M. Origins of mineral matter in peat marsh and peat bog deposits, Spain. International Journal of Coal Geology, 2007, vol. 71, pp. 246-262. DOI: 10.1016/j.coal.2006.09.001.

27. Cabala J., Smieja-Król B., Jablonska M., Chrost L. Mineral components in a peat deposit: looking for signs of early mining and smelting activities in Silesia-Cracow region (Southern Poland). Environmental Earth Sciences, 2013, no. 69, pp. 2559-2568. DOI: $10.1007 / \mathrm{s} 12665-012-2080-6$.

28. Zaccone C., Pabst S., Senesi G.S., Shotyk W., Miano T.M. Comparative evaluation of the mineralogical composition of Sphagnum peat and their corresponding humic acids, and implications for understanding past dust depositions. Quaternary International, 2013, no. 306, pp. 80-87. DOI: 10.1016/j.quaint.2013.04.017.

Received: 26 August 2019.

\section{Information about the authors}

Oleg G. Savichev, Dr. Sc., professor, National Research Tomsk Polytechnic University.

Nina G. Nalivaiko, Cand. Sc., associate professor, National Research Tomsk Polytechnic University.

Maxim A. Rudmin, Cand. Sc., associate professor, National Research Tomsk Polytechnic University.

Aleksey K. Mazurov, Dr. Sc., professor, National Research Tomsk Polytechnic University. 